\title{
Antioxidant activity and cytotoxicity of the edible mushroom, Pleurotus cystidiosus against Hep-2 carcinoma cells
}

\author{
Inoka P. Menikpurage ${ }^{1}$, S.S.S.B.D.P. Soysa ${ }^{2}$ and D.T.U. Abeytunga ${ }^{1^{*}}$ \\ ${ }^{1}$ Department of Chemistry, Faculty of Science, University of Colombo, Colombo 03. \\ ${ }^{2}$ Department of Biochemistry and Molecular Biology, Faculty of Medicine, University of Colombo, Kynsey Road, P.O. Box 271, Colombo 08.
}

\begin{abstract}
This study was undertaken to evaluate the antioxidant activity and cytotoxicity of Pleurotus cystidiosus, an edible mushroom, against Hep-2 cancer cells. Fresh P. cystidiosus mushroom was extracted with acetone (fraction A). Fraction A was extracted into hexane, dichloromethane and ethyl acetate successively and the remaining fraction was labeled as "A4". Fraction A4 was further separated into three fractions, A4-1, A4-2 and A4-3 using a reverse phase column. 1,1-diphenyl-2picrylhydrazyl (DPPH) radical scavenging activity and nitric oxide (NO) radical scavenging activity assays were used to investigate the reducing power of the extracts. The DPPH- $\mathrm{EC}_{50}$ of A4-2 and A4-3 were 0.81 and $0.82 \mathrm{mg} / \mathrm{mL}$, respectively; $\mathrm{NO}-\mathrm{EC}_{50}$ of $\mathrm{A} 4-2$ and $\mathrm{A} 4-3$ were 0.87 and $0.61 \mathrm{mg} / \mathrm{mL}$, respectively. The results on cytotoxic effects based on MTT and LDH assays have shown that the same two extracts to have the highest activity. These results were reinforced by the cell morphological changes observed using an inverted fluorescence microscope of the treated cells. Cells incubated with the highest dose $(5 \mathrm{mg} / \mathrm{mL})$ of A4-2 and A4-3 showed cell morphological changes such as cellular swelling, irregular cell shapes, condensed cytoplasm and vacuolar areas. Hence it can be concluded that the extract of $P$. cystidiosus has antioxidative activity as well as cytotoxicity against Hep-2 cancer cells. It can also be speculated that the use of whole mushroom as a medicinal food may bring about health benefits.
\end{abstract}

Keywords: Abalone, DPPH radical scavenging activity, LDH activity, MTT, mushroom.

\section{INTRODUCTION}

The study of mushrooms during the last few decades has resulted in many beneficial products such as notable mycopharmaceuticals, myconutriceuticals and mycocosmeceuticals. Literature reveals that Pleurotus species commonly known as oyster mushrooms also posses many biological activities including promising anticancer and antioxidant activities (Wasser, 2002).

Cancer has become the second largest cause of death in humans, and has led to many research efforts and clinical studies to find potent cancer drugs (Daba \& Ezeronye, 2003). Treatments by chemotherapeutic agents, surgery and radiation have not been fully effective in control or prevention of many cancers (Moongkarndi et al., 2004). Medicinal mushrooms have been tested against several major cancers involving stomach, lung, liver and colon (Gu \& Sivam, 2006).

Approximately 200 species of mushrooms have been found to markedly inhibit tumor growth, but most of the compounds responsible for their activity have not yet been identified (Wasser \& Weis, 1999). Six of the polysaccharides of mushroom-origin that have been investigated with human cancers include lentinan, schizophyllan, active hexose correlated compounds (AHCC), maitake D-fraction, polysaccharide-K and polysaccharide-P (Daba \& Ezeronye, 2003). In a recent pilot study it has been reported that the administration of DNA isolated from the Pleurotus ostreatus fruit body, significantly increases the life span of mice with solid Ehrlich carcinoma (Shlyakhovenko et al., 2006).

The antioxidative activity of phytochemicals also plays an important role in anti-carcinogenic and antimutagenic activities (Padma et al., 2007). Various compounds of mushroom origin and extracts have shown radical scavenging activities with anticancer properties. Pleuran ( $\beta-1,3-D$ glucan) isolated from Pleurotus ostreatus fibre complex has stimulated the activity of the antioxidant enzymes such as superoxide dismutase and glutathione peroxidase activity in rat liver and has

* Corresponding author (thusitha@chem.cmb.ac.lk) 
reduced the glutathione levels significantly in rat colon (Bobek \& Galbavy, 2001). In several other studies Ganoderma lucidum, Phellinus rimosus, Pleurotus florida and Pleurotus pulmonaris have been observed to possess profound antioxidant and antitumor activities (Ajith \& Janardhanan, 2007).

There are no reports on the antioxidative activity and cytotoxicity of Pleurotus cystidiosus species, which is commonly referred to as abalone. P. cystidiosus mushroom is large and fleshy, and it grows on tree trunks or stumps in shelf-like layers. The pileus is shell-shaped and dark grayish brown in colour and the stipe is dark brown (Dube, 1996).

The present study investigated the antioxidant and cytotoxic activity of $P$. cystidiosus against Hep-2 cancer cell line and the most active $P$. cystidiosus fraction responsible for those activities.

\section{METHODS AND MATERIALS}

Chemicals: Eagle's minimum essentialmedium(EMEM), foetal bovine serum (FBS), antibiotics (penicillin/ streptomycin), trypsin (from porcine pancreas), ethylenediamine tetraacetic acid (EDTA), 3,4,5(dimethylthiazol-2-yl)2-5-diphenyl tetrazolium bromide (MTT), bovine serum albumin (BSA), and camptothecin were purchased from Sigma Chemicals Co., Ltd. (USA). L-Glutamine, 1,1-diphenyl-2-picrylhydrazyl (DPPH), polyethylene glycol tert-octylphenyl ether (Triton $\mathrm{X}-100)$ solution (1 \%), and dimethyl sulfoxide were purchased from Fluka Chemie GmbH (Switzerland). Ascorbic acid, sodium nitroprusside (SNP) and ethanol were purchased from BDH Chemicals Ltd. (England). All the other chemicals were obtained in the purest form available commercially. The lactate dehydrogenase (LDH) enzyme assay and the total protein kits were purchased from Randox Laboratories Ltd. (UK).

Cell culture: A Hep-2 cell line was obtained from the Medical Research Institute, Colombo 8. The cells were cultured in EMEM growth media supplemented with $10 \%$ FBS, MEM (1 \%), L-glutamine (3\%), 50 IU/ $\mathrm{mL}$ penicillin and $50 \mu \mathrm{g} / \mathrm{mL}$ streptomycin. The $\mathrm{pH}$ of the growth media was adjusted to physiological $\mathrm{pH}$ (7.4) using $7.5 \%$ sodium bicarbonate. The cells were maintained at $37{ }^{\circ} \mathrm{C}$ in a $5 \% \mathrm{CO}_{2}$ atmosphere with $95 \%$ humidity.

Preparation of $P$. cystidiosus mushroom extracts/ fractions: Extraction and fractionation of $P$. cystidiosus mushroom was carried out using the procedure of
Vasudewa et al. (2008). This procedure was very successful, giving a fraction with potent anti nociceptive activity. The summary of the procedure is as follows.

Fresh P. cystidiosus mushroom was extracted into acetone and the extract was labelled as "A". Fraction A was extracted successively into hexane (A1), dichloromethane (A2) and ethyl acetate (A3) and the remaining fraction was labelled as "A4". After the removal of all the solvents, fraction A4 (1g) was loaded onto a reverse phase column and three bulk fractions; A4-1, A4-2 and A4-3 were eluted with $100 \mathrm{~mL}$ each of $7: 3,1: 1$ and $3: 7$ water:methanol solution mixtures (Menikpurage et al., 2009). All extracts/fractions were subjected to rotary evaporation followed by freeze drying. In all cytotoxicity experiments, a negative control without $P$. cystidiosus extract/fraction and a positive control with $5 \mathrm{mM}$ camptothecin $(25 \mu \mathrm{L})$ were used.

\section{Determination of reducing power:}

a) DPPH free radical scavenging activity: The antioxidant activity of $P$. cystidiosus mushroom extracts/fractions was assayed using 1,1-diphenyl-2picrylhydrazyl (DPPH) scavenging method (Blois, 1958) with slight modifications.

A concentration series (1.0, 2.0, 5.0, 10.0, 20.0, 30.0 and $40.0 \mathrm{mg} / \mathrm{mL}$ ) of water soluble samples were prepared using freeze dried $P$. cystidiosus extracts/fractions. Each solution of $P$. cystidiosus extract/fraction $(50 \mu \mathrm{L})$ was added to a solution of DPPH reagent in ethanol $(100 \mu \mathrm{M} ; 950 \mu \mathrm{L})$. The mixtures were incubated at room temperature for $30 \mathrm{~min}$ in the dark and the absorbance of the resulting solutions were measured at $517 \mathrm{~nm}$. Controls were prepared using $50 \mu \mathrm{L}$ de-ionized water and $950 \mu \mathrm{L}$ DPPH reagent $\left(\mathrm{A}_{\text {control }}\right.$ ). Different concentrations of ascorbic acid $(2.5-75 \mu \mathrm{g} / \mathrm{mL})$ were used as the positive controls. The radical scavenging activity (\%) was obtained using the following equation.

$\begin{aligned} & \text { Radical scavenging } \\ & \text { activity }(\%)\end{aligned}=\frac{\left(\mathrm{A}_{\text {control }}-\mathrm{A}_{\text {sample }}\right)}{\mathrm{A}_{\text {control }}} \times 100 \%$

b)Nitric oxide radical scavenging activity: Nitric oxide generated from sodium nitroprusside (SNP) was measured using Griess reagent ( $1 \%$ sulfanilamide and $0.1 \%$ naphthylenediamine in $2 \% \mathrm{H}_{3} \mathrm{PO}_{4}$ ) according to Green et al., (1982) and Sumanont et al., (2004). SNP (100 $\mathrm{mM}$ ) was prepared by dissolving SNP in phosphate buffered saline (PBS) at $\mathrm{pH}$ 7.4. The reaction mixture $(2 \mathrm{~mL})$ containing the mushroom extract/fraction $(1 \mathrm{~mL})$, 
$100 \mathrm{mM} \mathrm{SNP}(0.2 \mathrm{~mL})$ and PBS $(0.8 \mathrm{~mL})$ was incubated at $25{ }^{\circ} \mathrm{C}$ for $3 \mathrm{~h}$. A control experiment was conducted using $100 \mathrm{mM}$ SNP $(0.2 \mathrm{~mL})$ and PBS $(1.8 \mathrm{~mL})$. After the incubation period, the sample $(1 \mathrm{~mL})$ was mixed with Griess reagent $(1 \mathrm{~mL})$ and the absorbance of the pink coloured azo dye was measured at $540 \mathrm{~nm}$. The final concentrations of the extract/fraction in these solutions were $0.25-3.0 \mathrm{mg} / \mathrm{mL}$. To exclude the interference of the other compounds in the extract/fractions with the absorbance value of nitrite detection, the absorbance of extract/fractions $(1.0 \mathrm{~mL})$ and PBS $(1.0 \mathrm{~mL})$ was also measured. The difference in the aforementioned absorbance values was used in the calculation of nitric oxide radical scavenging activity $\left(\mathrm{A}_{\text {sample }}\right)$ (equation 1$)$.

\section{Cytotoxic activity:}

\section{a) MTT assay:}

Hep-2 cells $\left(1 \times 10^{5}\right.$ cells/well) were seeded in 24 well plates (NUNC, Denmark) and cultured over-night. The cells were treated with 6 different concentrations of 5 different $P$. cystidiosus mushroom extracts prepared in culture medium; namely, fractions A, A4, A4-1, A4-2 and A 4-3 $(0.5,1.0,2.0,3.0,4.0$ and $5.0 \mathrm{mg} / \mathrm{mL})$ and incubated in a $\mathrm{CO}_{2}$ incubator at $37^{\circ} \mathrm{C}$ for $24 \mathrm{~h}$. Culture media without the extracts were used as negative controls. The supernatant was replaced with MEM $(0.5 \mathrm{~mL})$ followed by sterile $5 \mathrm{mg} / \mathrm{mL}$ MTT $(50 \mu \mathrm{L})$ and the cells were incubated $\left(37^{\circ} \mathrm{C}\right.$ for $\left.4 \mathrm{~h}\right)$ in the dark. The supernatant was removed carefully and the formed formazan crystals were fully dissolved in $700 \mu \mathrm{L}$ of $0.05 \mathrm{M}$ hydrochloric acid in isopropyl alcohol. It was centrifuged at $5000 \mathrm{x}$ g for $5 \mathrm{~min}$. The absorbance was measured at $570 \mathrm{~nm}$ (Fotakis $\&$ Timbrell, 2006) and the percentage cell viability was calculated using the following equation.

\section{Cell viability $(\%)=$ Absorbance of the sample $\times 100 \%$ Absorbance of the negative sample}

\section{b) Lactate dehydrogenase (LDH) activity:}

The LDH assay was performed (Fotakis \& Timbrell, 2006) by measuring the reduction of pyruvate to lactate by lactate dehydrogenase. Hep- 2 cells $\left(2 \times 10^{5}\right.$ cells/well $)$ were seeded in 12 well plates (NUNC, Denmark) and left to adhere to the plastic plates over-night in humidified atmosphere in a carbon dioxide incubator $\left(5 \% \mathrm{CO}_{2}\right)$ at $37^{\circ} \mathrm{C}$. Monolayers were treated with different concentrations of the $P$. cystidiosus extract A, fractions A4, A4-1, A4-2 and A4-3 (1.0, 2.0, 3.0, 4.0 and $5.0 \mathrm{mg} / \mathrm{mL}$ ) prepared in culture media and incubated in a $\mathrm{CO}_{2}$ incubator at $37^{\circ} \mathrm{C}$ for $24 \mathrm{~h}$. The supernatant was separated out and the cells were disrupted with $0.1 \%$ triton X-100 (2 mL). LDH activity of the supernatant and the lysate was measured using the LDH assay kit.

Griess nitrite assay: The nitric oxide content in the supernatant obtained from the LDH assay was estimated using the Griess nitrite assay (Green et al., 1982). The culture supernatant $(300 \mu \mathrm{L})$ obtained in the $\mathrm{LDH}$ assay was incubated with Griess reagent $(300 \mu \mathrm{L})$ at room temperature for $10 \mathrm{~min}$. The absorbance was measured at $540 \mathrm{~nm}$. The nitrite content was calculated based on a $\mathrm{NaNO}_{2}$ standard curve.

Estimation of protein content: The protein content in the cell lysate obtained in the LDH assay was determined using Randox total protein kit.

Determination of reduced glutathione: The reduced glutathione (GSH) content in the cell lysate obtained in the LDH assay was also determined using the methods given in Weisburg et al. (2004) and Padma et al. (2007) with slight modifications. The proteins of lysate $(500 \mu \mathrm{L})$ were precipitated with $2.5 \%$ sulfosalicylic acid and centrifuged. To $500 \mu \mathrm{L}$ of the clear supernatant, PBS (250 $\mu \mathrm{L})$ and 5,5'-dithiobis-2-nitrobenzoic acid $(50 \mu \mathrm{L})$ were added and the absorbance was measured immediately at $412 \mathrm{~nm}$. A series of reduced glutathione standards $(0.5-3 \mu \mathrm{g} / \mathrm{mL})$ treated in a similar manner were also run to determine the reduced glutathione content in cell lysate.

\section{c) Morphological determination:}

The morphological changes of cells after the treatment with $P$. cystidiosus extract A, fractions A4, A4-1, A4-2 and A4-3 (1.0, 2.0, 3.0, 4.0 and $5.0 \mathrm{mg} / \mathrm{mL})$ over $24 \mathrm{~h}$ were detected by microscopic examination of cells. Photographs of morphological changes were compared with negative and positive controls.

In all cytotoxicity experiments, a negative control without the $P$. cystidiosus extract/fraction and a positive control with $5 \mathrm{mM}$ camptothecin $(25 \mu \mathrm{L})$ were used.

Statistical analysis: All experiments were performed in triplicate. The effective concentration of sample required to scavenge radicals by $50 \%\left(\mathrm{EC}_{50}\right)$ was obtained by linear regression analysis using the linear segment of the dose response curve plotted with radical scavenging activity (\%) vs concentration of the mushroom extract/ fraction. Graphical data were presented as mean \pm standard error of the mean (SEM). 


\section{RESULTS}

\section{Determination of reducing power}

\section{DPPH free radical scavenging activity}

The DPPH free radical scavenging activity of P. cystidiosus extract A, fractions A4, A4-1, A4-2 and A4-3 was dose dependent and increased as the dose increased. The $\mathrm{EC}_{50}$ values of extract A, fractions A4, A4-1, A4-2 and A4-3 obtained were 1.12, 1.13, 0.87, 0.81 and $0.82 \mathrm{mg} / \mathrm{mL}$, respectively (Figure 1). Ascorbic acid was used as the standard antioxidant and the $\mathrm{EC}_{50}$ value obtained for ascorbic acid was $0.044 \mathrm{mg} / \mathrm{mL}$.

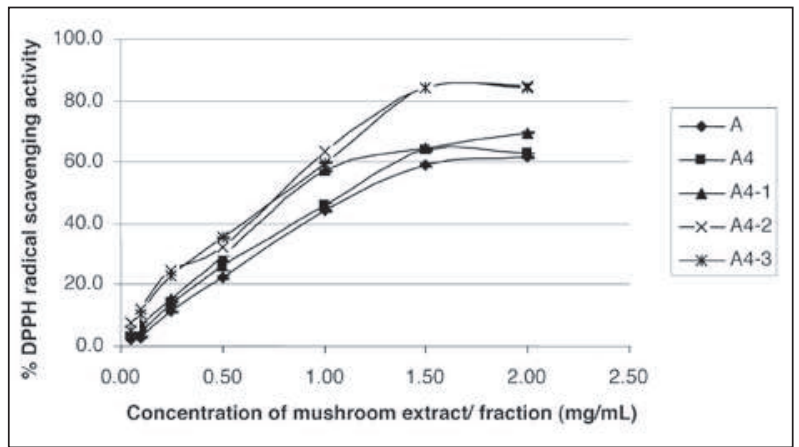

Figure 1: Percentage DPPH radical scavenging activity of P. cystidiosus extract A and fractions A4, A4-1, A4-2 and A4-3

\section{Nitric oxide radical scavenging activity:}

SNP in aqueous medium at physiological $\mathrm{pH}$, spontaneously generates nitric oxide; it interacts with

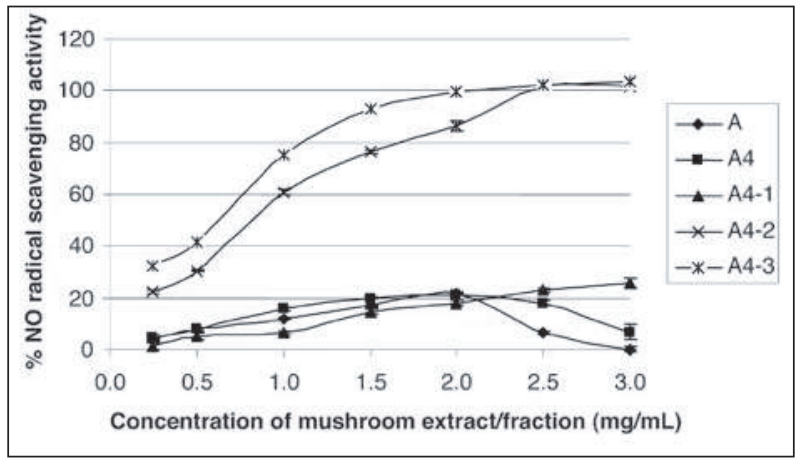

Figure 2: Nitric oxide radical scavenging activity (\%) of $P$. cystidiosus extract A and fractions A4, A4-1, A4-2 and A4-3 oxygen to produce nitrite ions, which were estimated using Griess reagent. $\mathrm{EC}_{50}$ values for P. cystidiosus extract A and fractions A4, A4-1, A4-2 and A4-3 from the nitric oxide radical scavenging activity assay were $4.81,3.82$, $5.38,0.87$ and $0.61 \mathrm{mg} / \mathrm{mL}$, respectively (Figure 2).

\section{Cytotoxic activity}

\section{MTT assay}

MTT assay was used to determine the cell viability of Hep-2 cancer cells. The percentage cell viability in the presence of $P$. cystidiosus samples A, A4, A4-1, A4-2 and A4-3 decreased as shown in Figure 3 and dose dependent declines in cell viability were observed in all the fractions except A4-1. The percentage cell viability (mean $\pm \mathrm{SEM}$ ) of the positive control, camptothecin was $43.7 \pm 2.0 \%$.

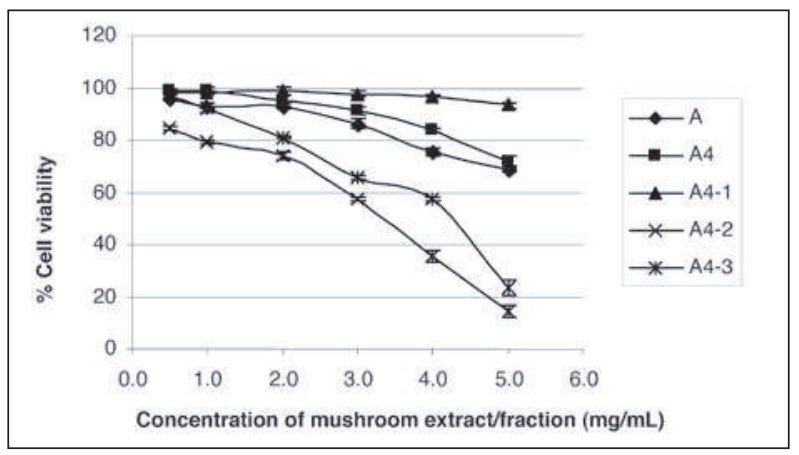

Figure 3: Percentage cell viability of Hep-2 cells induced by P. cystidiosus extract A and fractions A4, A4-1, A4-2 and A4-3 in MTT assay

\section{Lactate dehydrogenase ( $\mathrm{LDH})$ activity}

The NADH remaining in the mixture was used to calculate the lactate dehydrogenase released from Hep-2 cells. A dose dependent increase of LDH release (Figure 4) was observed with A, A4, A4-1, A4-2 and A4-3. Mean \pm SEM LDH release percentage of the positive control was 57.7 $\pm 3.9 \%$.

\section{Griess nitrite assay}

The nitrite level of A4-2 and A4-3 fractions treated cell supernatant obtained from the LDH assay resulted in dose independent decreases compared to the negative control (Figure 5). The nitrite levels of the other fractions were not dose dependent. 


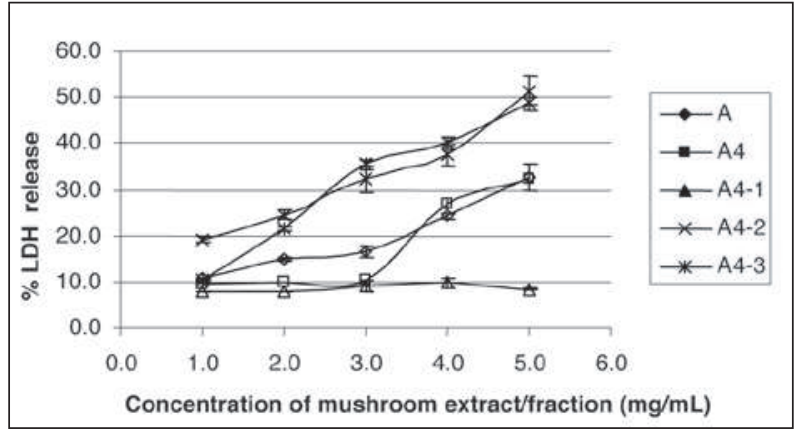

(a)

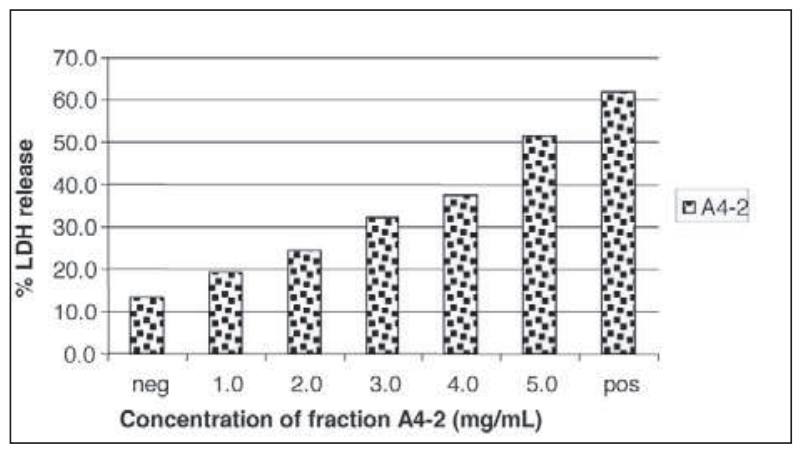

(b)

Figure 4: (a) Percentage of LDH release, which is induced by the exposure to $P$. cystidiosus extract A and fractions A4, A4-1, A4-2 and A4-3 (b) Percentage of LDH release at different concentrations of A4-2 fraction of P. cystidiosus

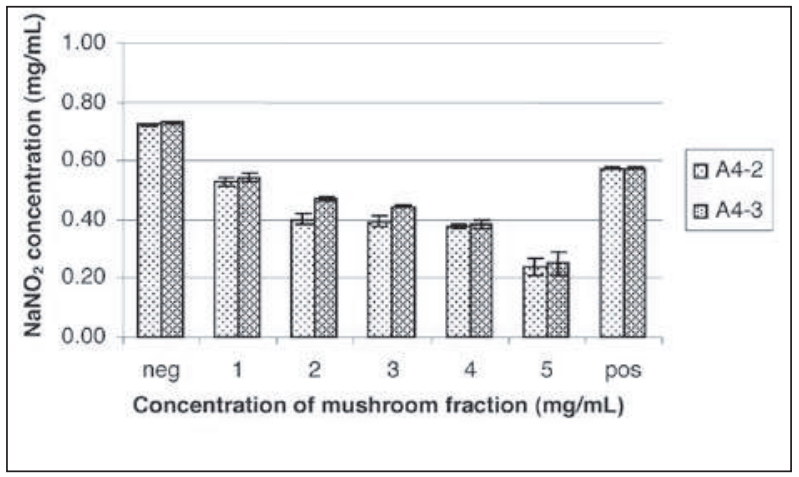

Figure 5: $\mathrm{NaNO}_{2}$ content $(\mathrm{mg} / \mathrm{mL})$ in the supernatant after treating with P. cystidiosus fractions A4-2 and A4-3

\section{Protein content}

A dose dependent decrease in protein synthesis could be observed for A4, A4-2 and A4-3 fractions (Figure 6).

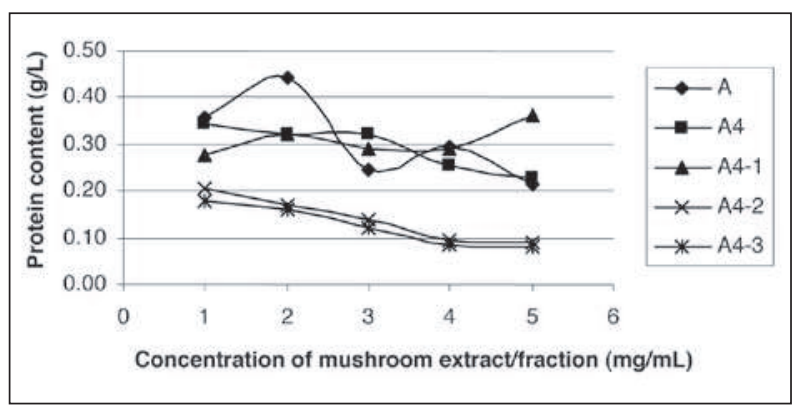

Figure 6: Protein content of lysate after treating with P. cystidiosus extract A and fractions A4, A4-1, A4-2 and A4-3

\section{Reduced glutathione}

Glutathione content of lysate after treating with P. cystidiosus extract A and fractions A4, A4-1, A4-2 and A4-3 did not show any dose dependent relationship (data not given).

\section{Cell morphological changes}

The Hep-2 cells treated with P. cystidiosus A, A4, A4-1, A4-2 and A4-3 preparations were observed using an inverted fluorescence microscope (Figure 7). The untreated cells appeared elongated in shape and were attached smoothly to the culture surface, forming a monolayer. The cells treated with P. cystidiosus A, A4, A4-2 and A4-3 had lost their integrity and appeared rounded. The cells treated with A4-2 and A4-3 showed higher numbers of dead cells with the increase in concentration.

\section{DISCUSSION}

Mushrooms have recently become important for drug development. Many investigators have isolated and identified antitumor compounds of mushroom origin such as lentinan, $\beta$-glucans (Mizuno et al., 2001), lucidenic acids (Hsu et al., 2008), and ergosterol peroxide (Kobori et al., 2007). The results obtained in this study shows that the edible mushroom $P$. cystidiosus is a rich source of antioxidants and has cytotoxic activities against Hep-2 carcinoma cells.

DPPH radical scavenging activity and nitric oxide radical scavenging activity were measured to investigate the reducing power of $P$. cystidiosus. DPPH radical scavenging assay has been widely used to measure 


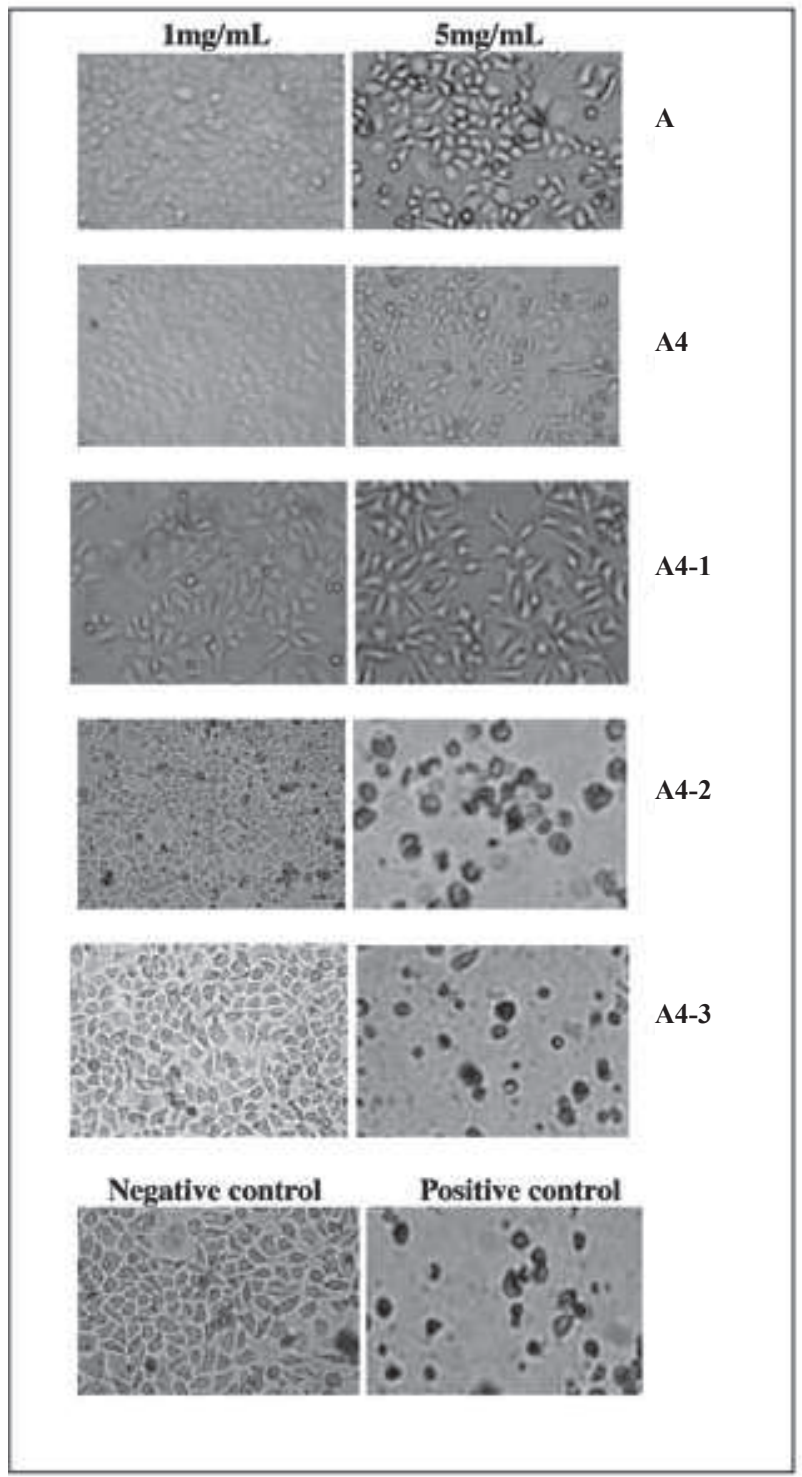

Figure 7: Morphological observation of Hep-2 cells after 24 hour exposure with acetone extract and derived subfractions of $P$. cystidiosus extracts. The cell morphology was observed using an inverted microscope at $200 \times$ magnification (Olympus IX 70). Cell death was indicated by cell shrinkage, cell disintegration and reduction in cell number. Positive control has the cells incubated with camptothecin $(5 \mathrm{mM}$; $25 \mu \mathrm{L})$.

radical scavenging activity. DPPH radicals in the presence of suitable reducing agents decrease the colour stoichiometrically, with the number of electrons consumed and can be measured spectrometrically (Govindarajan et al., 2003). As shown in Figure 1, fractions A4-2 and A4-3 effectively scavenged DPPH radicals with $\mathrm{EC}_{50}$ values of 0.81 and $0.82 \mathrm{mg} / \mathrm{mL}$, respectively. The $\mathrm{EC}_{50}$ value of the standard ascorbic acid was $0.044 \mathrm{mg} / \mathrm{mL}$.

Nitric oxide acts as a mediator of physiological processes such as neuronal signaling, inhibition of platelet aggregation and regulation of cell mediated toxicity (Govindarajan et al., 2003; Sumanont et al., 2004). In the presence of nitrite ions formed by the oxidation of nitric oxide, sulfanilic acid is quantitatively converted to a diazonium salt under acidic conditions. Then the diazonium salt reacts with $\mathrm{N}$-(1-naphthyl) ethylenediamine dihydrochloride to form the red pink azo dye, which can be spectrometrically measured at $540 \mathrm{~nm}$. P. cystidiosus preparations facilitated nitric oxide scavenging activity in a dose dependent manner (Figure 2). As in the DPPH assay, fractions A4-2 and A4-3 showed high NO scavenging activities. The free radical scavenging activity and inhibition of nitric oxide production of Trichoma matsutate Sing. (pine mushroom) have been reported (Lim et al., 2007). This supports the results obtained from our studies of DPPH and NO scavenging activities of $P$. cystidiosus.

To determine the possibility of using $P$. cystidiosus as an anticancer agent, cytotoxic effects, cell viability and antiproliferative activity were assayed using MTT and LDH assays.

The MTT assay (Fotakis \& Timbrell, 2006) is based on the ability of metabolically active cells to reduce MTT [3-(4,5-dimethylthiazol-2-yl)-2,5-diphenyltetrazolium bromide] to blue formazan compounds by mitochondrial dehydrogenases. The reduction of absorbance in samples treated with mushroom extract/fraction reflects the reduction of the cell viability in the aforementioned samples. The observed reduction in cell viability is due to the cytotoxicity of the mushroom extracts towards the cells. Fraction A4-1 had no effect on cytotoxic assays. The cytotoxic effect of $P$. cystidiosus extract A on cell population growth of Hep-2 cells increased with the concentration. Fraction A4-2 and A4-3 had high activities. The cytotoxicities of the samples were A4-2 >A4-3>A4 $>\mathrm{A}$ in a dose dependent manner (Figure 3). The $50 \%$ cell viability of fractions A4-2 and A4-3 were $3.1 \mathrm{mg} / \mathrm{mL}$ and $3.6 \mathrm{mg} / \mathrm{mL}$, respectively. Lucidenic acids (A, B, C and $\mathrm{N}$ ) isolated from Ganoderma lucidium have shown decreased cell population growth of HL-60 carcinoma cells assessed with MTT assay (Hsu et al., 2008).

In the LDH assay, the reduction of pyruvic acid to lactic acid is determined by measuring the NADH remaining in the reaction mixture (Lopez et al., 2003). 
The $\mathrm{LDH}$ release increased with the concentration of extracts, except in fraction A4-1. The highest LDH release was observed in the samples treated with A4-2 (Figure 4). The percentage $\mathrm{LDH}$ release with $5 \mathrm{mg} / \mathrm{mL}$ extract were $51.1 \pm 1.5,48.7 \pm 2.9,32.7 \pm 3.0$ and $32.2 \pm$ $2.5 \%$ for A4-2, A4-3, A and A4, respectively.

Overproduction of NO can mediate toxic effects such as DNA fragmentation, cell damage and neuronal cell death (Dawson et al., 1992; Forrester et al., 1996). In this study, decrease in nitric oxide generation was observed in the supernatants of A4-2 and A4-3 treated samples (Figure 5). This augments the results obtained for NO radical scavenging activities (Figure 2) in establishing the fact that extracts A4-2 and A4-3 are effective in reducing $\mathrm{NO}$ radical generation as well as scavenging the NO generated.

A dose dependant decrease in total protein content (Figure 6) was observed for A4, A4-2 \& A4-3 fractions and this too supports the results obtained from cytotoxic assays.

Cell morphological changes were observed for Hep-2 cells treated with extracts A, A4, A4-1, A4-2, A4-3 in order to strengthen the results obtained from MTT and LDH assays. Cells incubated with the highest doses of A4-2 and A4-3 showed cell morphological changes such as cellular swelling, irregular cell shapes, condensed cytoplasm and vacuolar areas.

GSH plays an important role in protection of cells against oxidative stress. It reduces $\mathrm{H}_{2} \mathrm{O}_{2}$ directly to water, forming oxidized glutathione (Padma et al., 2007). However, the GSH levels recorded did not show any relationship to the extract concentrations.

Antiproliferation and the removal of malignant cells through apoptosis have become a positive strategy in cancer prevention. In addition, many studies have demonstrated that antioxidative compounds play an important role in cancer prevention (Hou, 2003). In this study, P. cystidiosus fractions A4-2 and A4-3 demonstrated high antioxidant activities and antiproliferative activities. Thus, $P$. cystidiosus has promising activity as an anticancer agent.

Our previous studies have shown that consumption of P. cystidiosus (Kudahewa et al., 2008) or P. ostreatus (Vasudewa et al., 2007) may be beneficial as a remedy for body aches and pains arising due to daily activities. This study shows that extracts of $P$. cystidiosus has antioxidant and anticancer properties. We conclude that the mushroom P. cystidiosus may have disease preventing and curing properties beyond the basic function of providing nutrients.

\section{Acknowledgement}

We acknowledge the financial support from NSF grants $\mathrm{RG} / 2004 / \mathrm{C} / 2$ and $\mathrm{RG} / 2005 / \mathrm{HS} / 17$.

\section{REFERENCES}

1. Ajith T.A. \& Janardhanan K.K. (2007). Indian medicinal mushrooms as a source of antioxidant and antitumor agents. Journal of Clinical Biochemistry and Nutrition 40(03): 157-162.

2. Blois M.S. (1958). Antioxidant determination by the use of stable free radical. Nature 181: $1199-1200$.

3. Bobek P. \& Galbavy S. (2001). Effect of pleuran (betaglucan from Pleurotus ostreatus) on the antioxidant status of the organism and on dimethylhydrazine-induced precancerous lesions in rat colon. British Journal of Biomedical Science 58(03): $164-168$.

4. Daba A.S. \& Ezeronye O.U. (2003). Anti-cancer effect of polysaccharides isolated from higher basidiomycetes mushrooms. African Journal of Biotechnology 2(12): 672-678.

5. Dawson T.M., Dawson V.L. \& Synder S.H. (1992). A novel neuronal messenger molecule in brain: the free radical, nitric oxide. Annals of Neurology 32(03): 297-311.

6. Dube H.C. (1996). An Introduction to Fungi, p. 372. Vikas Publishing House Pvt. Ltd., Delhi, India.

7. Forrester K., Ambs S., Lupold S.E., Kapust R.B., Spillare E.A., Weinberg W.C., Felley-Bosco E., Wang X.W., Geller D.A., Tzeng E., Billiar T.R. \& Harris C.C. (1996). Nitric oxide-induced p53 accumulation and regulation of inducible nitric oxide synthase expression by wild-type p53. Proceedings of the National Academy of Sciences, USA 93(06): 2442-2447.

8. Fotakis G. \& Timbrell J.A. (2006). In vitro cytotoxicity assays: comparison of LDH, neutral red, MTT and protein assay in hepatoma cell lines following exposure to cadmium chloride. Toxicology Letters 160(02): 171-177.

9. Govindarajan R., Rastogi S., Viayakumar M., Shirwaikar A., Rawat A.K., Mehrotra S. \& Pushpangadan P. (2003). Studies on the antioxidant activities of Desmodium gangeticum. Biological and Pharmaceutical Bulletin 26: $1424-1427$.

10. Green L.C., Wagner D.A., Glogowski J., Skipper P.L., Wishnok J.S. \& Tannenbaum S.R. (1982). Analysis of nitrite, nitrate and $\mathrm{N}^{13}$ in biological fluids. Analytical Biochemistry 126: 131-138.

11. Gu Y.H. \& Sivam G. (2006). Cytotoxic effect of oyster mushroom Pleurotus ostreatus on human androgenindependent prostate cancer PC-3 cells. Journal of Medicinal Food 9(02): 196 -204. 
12. Hou X. (2003). Potential mechanisms of cancer chemoprevention by anthocyanins. Current Molecular Medicine 3(02): 149-159.

13. Hsu C.L., Yu Y.S. \& Yen G.C. (2008). Lucidenic acid $\mathrm{B}$ induces apoptosis in human leukemia cells via a mitochondria-mediated pathway. Journal of Agricultural and Food Chemistry 56: 3973 - 3980.

14. Kobori M., Yoshida M., Kameyama M.O. \& Shinmoto H. (2007). Ergosterol peroxide from an edible mushroom suppress inflammatory responses in RAW264.7 macrophages and growth of HT29 colon adenocarcinoma cells. British Journal of Pharmacology 150: 209 -219.

15. Kudahewa D.D., Abeytunga D.T.U. \& Ratnasooriya W.D. (2008). Antinociceptive activity of Pleurotus cystidiosus, an edible mushroom in rats. Pharmacognosy Magazine 4: $37-41$.

16. Lim H.W., Yoon J.H., Kim Y.S., Lee M.W., Park S.Y., \& Kyoon H. (2007). Free radical-scavenging and inhibition of nitric oxide production by four grades of pine mushroom (Tricholoma matsutake Sing.). Food Chemistry 103: 13371342.

17. Lopez E., Figueroa S., Gasque M.J.O. \& Gonzalez M.P. (2003). Apoptosis necrosis: two distinct events induced by cadmium in cortical neurons in culture. British Journal of Pharmacology 138: 901-911.

18. Menikpurage I.P., Abeytunga D.T.U., Jacobson N.E. \& Wijesundara R.L.C (2009). An oxidized ergosterol from Pleurotus cystidiosus active against anthracnose causing Colletotrichum gloeosporioides. Mycopathologia 167: 155-162.

19. Mizuno M., Minato K., Kawakami S., Tatsuoka S., Denpo Y. \& Tsuchida H. (2001). Contents of antitumor polysaccharides in certain mushrooms and their immunomodulating activities. Food Science and Technology Research 7(01): 31-34.
20. Moongkarndi P., Kosem N., Kaslungka S., Luanratana O., Pongpan N. \& Neungton N. (2004). Antiproliferation, antioxidation and induction of apoptosis by Garcinia mangostana (mandosteen) on SABR3 human breast cancer cell line. Journal of Ethnopharmacology 90: 161-166.

21. Padma V.V., Christie S.A.D. \& Ramkuma K.M. (2007). Induction of apoptosis by ginger in HEp-2 cell line is mediated by reactive oxygen species. Basic Clinical Pharmacology and Toxicology 100: 302-307.

22. Shlyakhovenko V., Kosak V. \& Olishevsky S. (2006). Application of DNA from mushroom Pleurotus ostreatus for cancer biotherapy: a pilot study. Experimental Oncology 28(02): 132-135.

23. Sumanont Y., Murakami Y., Tohda M., Vajragupta O., Matsumoto K. \& Watanabe H. (2004). Evaluation of the nitric oxide radical scavenging activity of manganese complexes of curcumin and its derivative. Biological and Pharmaceutical Bulletin 27(02): 170 -173.

24. Vasudewa N.S., Abeytunga D.T.U. \& Ratnasooriya W.D. (2008). Activity-directed fractionation of Pleurotus ostreatus in the search for analgesics. Pharmaceutical Biology 46(05): 295 -301.

25. Wasser S.P. (2002). Review of medicinal mushrooms advances: good news from old allies. HerbalGram 56: 28-33.

26. Wasser S.P. \& Weis A.L. (1999). Medicinal properties of substances occurring in higher basidiomycetes mushrooms: current perspectives. International Journal of Medicinal Mushrooms 1: 31- 62.

27. Weisburg J.H., Weissman D.B., Sedaghat T. \& Babich H. (2004). In vitro cytotoxicity of epigallocatechin gallate and tea extracts to cancerous and normal cells from the human oral cavity. Basic and Clinical Pharmacology and Toxicology 95: 191-200. 